dr hab. Katarzyna Materska, prof. UKSW

Uniwersytet Kardynała Stefana Wyszyńskiego $w$ Warszawie

katarzyna.materska@gmail.com

\title{
ZARZĄDZANIE INFORMACJĄ - DOBRZE ZAINWESTOWANE PIENIĄDZE BIBLIOTEKI
}

\author{
INFORMATION MANAGEMENT - WELL-INVESTED \\ MONEY OF THE LIBRARY
}

\begin{abstract}
Abstrakt
W artykule starano się wykazać, że zarządzanie informacją może być traktowane jako narzędzie minimalizowania kosztów funkcjonowania biblioteki. Postawiono wiele pytań, które powinny być pomocne $\mathrm{w}$ efektywnym ich wykorzystaniu przez kadrę menedżerską. Brak stosowania zarządzania informacją w bibliotece może wywoływać nie tylko niekorzystne skutki finansowe, ale także społeczne.
\end{abstract}

Słowa kluczowe: zarządzanie informacją, koszty biblioteki, strategia informacyjna, polityka informacyjna.

\begin{abstract}
The hipothesis of the article is that information management can be perceived as a tool in the perspective of minimizing the costs of the library. The author asks a lot of questions, which should be helpful for the management staff in a most efficient way. The lack of the information management procedures can evoke not only financial, but unwanted social impact as well.
\end{abstract}

Keywords: information management, library cost, information strategy, information policy. 


\section{Zarządzać informacją}

Pieniądze na funkcjonowanie bibliotek są zasobem, któremu kadry menedżerskie tych instytucji nieustająco i prawdopodobnie coraz usilniej poświęcają swój czas, energię i wiedzę. Wydaje się, że wśród wielu zabiegów pozyskiwania bądź oszczędności finansowych środków, warto zwrócić uwagę na zarządzanie informacją (ZI), które w kontekście niniejszych rozważań potraktowane zostanie jako obszar podejmowania decyzji menedżerskich, służących m.in. minimalizowaniu i realokacji kosztów funkcjonowania biblioteki na polu spraw związanych $\mathrm{z}$ informacją. $\mathrm{W}$ tej perspektywie zasoby finansowe, informacyjne czy ludzkie traktowane są jako tak samo ważne.

Przyjmując, że ZI jest integralną częścią procesu zarządzania, uwaga menedżerów kierowana być musi w stronę planowania, przewidywania, implementacji, organizowania i kontroli zasobów informacji, systemów (w których jest przechowywana, przetwarzana i udostępniana), w stronę procesów i infrastruktury, a także szkoleń, promocji, kontroli i innych aktywności menedżerskich związanych $\mathrm{z}$ tworzeniem, zbieraniem, przetwarzaniem, utrzymywaniem, obiegiem, selekcją, długoterminową ochroną oraz wykorzystywaniem informacji. Stąd też ZI zdefiniowano w tym artykule jako uświadomione, systematyczne, kompleksowe i odpowiedzialne działania zogniskowane na informacji w celu jak najbardziej efektywnego (w tym ekonomicznego) ich gromadzenia, tworzenia, organizowania, transferu i wykorzystania przez biblioteki i ich pracowników.

\section{Strumienie informacji w bibliotece}

Bombardowani na co dzień różnorodną informacją, prawdopodobnie nie zdajemy sobie sprawy, jak wiele potrzebnej nam informacji wymaga jednak celowego jej zbierania i tworzenia, planowania treści i formy, właściwego rozmieszczenia i zabezpieczenia, systematycznego monitorowania, porządkowania, kontroli itd. Obserwacja przepływu informacji w bibliotece pozwala dostrzec następujące cztery grupy:

- informacje tworzone w bibliotece (przez bibliotekę);

- informacje tworzone w bibliotece przez jej czytelników, użytkowników, klientów;

- informacje powstające $\mathrm{w}$ otoczeniu biblioteki - pozyskiwane/ /wpływające do biblioteki (inne niż zakup);

- informacje kupowane przez bibliotekę wraz z zasobami w postaci 
np. baz danych, komercyjnych serwisów pełnotekstowych lub wraz ze sprzętem i aplikacjami (np.: prawa dostępu, licencje, szkolenia, instrukcje obsługi).

Każda z tych grup jest zróżnicowana wewnętrznie i może być dzielona dalej. Dla przykładu informacje tworzone w bibliotece przez bibliotekę obejmują:

- informacje przeznaczone dla jej użytkowników (np.: w postaci instrukcji, regulaminów, szkoleń, katalogów, baz danych, oznakowania biblioteki, na oficjalnej stronie domowej biblioteki, w serwisach społecznościowych, na plakatach, zaproszenia);

- informacje przeznaczone dla otoczenia/interesariuszy zewnętrznych (np.: sprawozdania dla władzi i na potrzeby statystyki krajowej, BIP, korespondencja biblioteki, informacje projektowe, materiały reklamowe i promocyjne, wywiady, filmiki na YouTube, artykuły w prasie branżowej i innych publikacjach - często powstają one $\mathrm{w}$ ramach polityki informacyjnej biblioteki);

- informacje na potrzeby funkcjonowania biblioteki (np.: regulaminy dla pracowników, opisy stanowisk pracy, plany urlopów, strategie i plany działania, harmonogramy prac, statystyki, sprawozdania działów).

W rzeczywistości grupy te często nie są rozłączne, co znakomicie ilustruje przykład informacji zbieranej i przygotowywanej przez bibliotekę na potrzeby projektu, którym posłużymy się w dalszej części artykułu.

\section{Cele zarządzania informacją}

Niezmiernie ważne jest zdefiniowanie celów ZI. Po części cele te są odbiciem nie tylko tego, jaką wartość nadajemy informacji w konkretnych działaniach, ale przede wszystkim tego, co chcemy osiągnąć - jakie funkcje informacja ma pełnić w danym przypadku (np.: powiadamiającą, stymulującą, decyzyjną, ostrzegawczą, porównawczą).

W różnych uwarunkowaniach wyznacza się rozmaite cele ZI: lepsze osiąganie strategicznych priorytetów, poprawę komunikacji wewnętrznej, uniknięcie ryzyka, zwiększenie wartości usług informacyjnych, ułatwienie współpracy na polu lepszej wymiany informacji pomiędzy pracownikami, efektywniejsze dokumentowanie pracy biblioteki dla przyszłości. Celem szczegółowym może być np. zapewnienie, że: tworzona i dostarczana jest informacja wysokiej jakości; dostarczanie informacji jest skuteczne; informacja jest zabezpieczona zgodnie $\mathrm{z}$ wymaganiami prawnymi i polityką informacyjną; informacja jest poddawana regularnej selekcji 
i usuwana zgodnie $\mathrm{z}$ wymaganiami prawnymi i polityką informacyjną biblioteki itd. Właściwe (przemyślane) postawienie celów, dostosowanych do aktualnych zadań, pozwala dobrać odpowiednie środki i sposoby realizacji, ustalić priorytety, plany i harmonogramy ZI. W prezentowanym przypadku za cel postawiono zmniejszanie kosztów biblioteki poprzez działania w obszarze ZI.

\section{Jak potrzeby informacyjne związane z projektem uruchamiają zarządzanie informacją?}

Za Ryszardem Zygałą możemy powtórzyć, że: „miejsce zarządzania informacją jest [...] tam, gdzie w organizacji »rodzi się« potrzeba informacyjna"'. Projekty, do których coraz liczniej przystępują biblioteki, wymagają planowania, monitorowania, kontroli, ewaluacji, wymagają także zasilenia odpowiednimi źródłami, informacjami, danymi. Istotnym parametrem projektu są także koszty jego opracowania - często będące wkładem własnym biblioteki. Przygotowanie projektu jest de facto zadaniem zespołowym i dlatego też wymaga ZI na różnych poziomach zarządzania biblioteką (zarówno strategicznym, jak i operacyjnym), obejmując następujące aspekty:

- zasobowy - zarządzanie zasobami informacyjnymi (Co?);

- procesowy-zarządzanie procesami informacyjnymi(Jak? W jakim celu?);

- strukturalny - zarządzanie strukturami organizacyjnymi odpowiednimi dla realizacji procesów ZI (Gdzie?);

- podmiotowy - zarządzanie ludźmi - osobami odpowiedzialnymi za inicjowanie i realizację procesów ZI w bibliotece (Kto?);

- czasowy (temporalny) - zarządzanie czasem (Kiedy?).

Skuteczność ZI często mierzona jest umiejętnością zadawania pytań, które postawić należy zwłaszcza w początkowej fazie przygotowań uruchomienia nowego programu, usługi czy projektu. Przykłady pytań, z uwzględnieniem wskazanych aspektów znajdziemy poniżej.

\section{ASPEKT ZASOBOWY}

Jakiej informacji potrzebujemy? Które już mamy? Jakie informacje musimy wytworzyć? W jakiej formie? Czy każda jest datowana, podpisana? (jakość); Czy informacje łatwo zestawiać, porównywać, analizować?

1 R. Zygała: Podstawy zarządzania informacja w przedsiębiorstwie. Wrocław 2007, s. 57. 
(spójność, porównywalność danych); Czy przygotowana informacja właściwie/wystarczająco dokumentuje to, co dzieje się/będzie się działo w bibliotece, w projekcie? Które informacje powinny być chronione?

\section{ASPEKT PROCESOWY I STRUKTURALNY}

Czy gromadzona i wytwarzana informacja jest dostępna, łatwa do odszukania? Jak jest zorganizowana informacja? (segregatory papier; wersje cyfrowe - arkusze kalkulacyjne, baza danych, wizualizacje, inne formaty); Gdzie jest przechowywana (cyfrowa platforma - dyski sieciowe...)? Jak informacja jest opisana (metadane)? Czy są narzędzia do analizowania i przetwarzania informacji? Jakie narzędzia w bibliotece wspierają procesy dzielenia się wiedzą? Gdzie informacja jest/powinna być przechowywana? (jeśli jest to informacja publiczna - czy biblioteka udostępnia swoje sprawozdania publicznie?); Jaką informacją należy się dzielić - szeroko rozpowszechnić? Jak promować informację do wykorzystania i ponownego wykorzystania (reuse)? Jak informacja jest zabezpieczona, archiwizowana? Która powinna zostać zachowana (zarchiwizowana) i na jak długo? Z wykorzystaniem jakich procedur?

\section{ASPEKT PODMIOTOWY}

Kto co robi (dyrektor, sekretarka, inne wyznaczone osoby)? Kto zbierze, przygotuje, opracuje informacje? Kto jest za informacje (treść) odpowiedzialny? Kto kontroluje treść i formę informacji? Kto nadaje informacji priorytety (prowadzi selekcję)? Czy pracownicy odpowiedzialni za zarządzanie informacją $\mathrm{w}$ organizacji są świadomi swoich obowiązków? Czy wytypowane osoby posiadają wystarczające kompetencje? Czy $\mathrm{w}$ związku z realizacją zadania konieczne jest wysłanie pracownika na szkolenie, instruktaż? Kogo i w jaki sposób nagradzamy za pomysłowość, sprawność, zaangażowanie?

\section{ASPEKT CZASOWY}

Ile czasu zabierze nam zebranie i opracowanie informacji (czas jako miara jakości usług)? Ile mamy czasu na zebranie, opracowanie i odesłanie informacji? Ile czasu przeznaczamy na poszczególne etapy? Do kiedy informacje muszą zostać przesłane (np. grantodawcom, kooperantom)? Która powinna zostać zachowana (zarchiwizowana) i na jak długo? Kiedy (po jakim czasie) i którą informację możemy (prawnie) usunąć? Co uzasadnia (nie uzasadnia) tak długi czas przygotowania przez nas informacji? 
Co poprawiamy w przyszłym roku? Z punktu widzenia przyjętej tu ramy „ekonomicznej” ZI zasadne jest pytanie o to, które z aspektów generują najwyższe koszty dla biblioteki? Wskazanie i analiza „słabych” punktów wyznacza kierownictwu obszar ,interwencyjny”, uruchamia procedury zarządcze. W efekcie poprawia efektywność kosztową - czaso- i energochłonną (czas przygotowania przedsięwzięcia liczony $\mathrm{w}$ godzinach pracy bibliotekarzy oraz eksploatacji systemów), materiałochłonną - także w sensie przygotowania bardziej syntetycznej, ale jednocześnie bardziej „przemawiającej” i przekonującej grantodawców informacji (np. zwizualizowanej). Podany tu przykład postępowania przy tworzeniu nowego projektu, usługi czy wydarzenia (własnego lub w konsorcjum) do pewnego stopnia powielany jest przy wielu innych zadaniach informacyjnych biblioteki, takich jak: strategia, misja, wizja, plany rzeczowo-finansowe; sprawozdawczość (wewnętrzna i zewnętrzna, np.: dla rektora, dla Senatu, raporty dla kwestury, statystyki wykorzystania baz danych, serwisów pełnotekstowych, e-książek, dla GUS, AFBN); korespondencja z władzami i jednostkami uczelni; regulaminy, instrukcje, zarządzenia wewnętrzne; sprawy pracownicze - zakresy obowiązków pracowników, konkursy o zatrudnienie; umowy z dostawcami, sponsorami; prowadzenie i analiza badań potrzeb użytkowników; monitorowanie regulacji prawnych wewnętrznych (np. uczelni) i zewnętrznych; benchmarking (porównywanie własnej biblioteki z najlepszymi). We wszystkich tych zadaniach kluczowe jest łatwe, szybkie i efektywne docieranie do rzetelnej, sprawdzonej informacji, sprawne jej tworzenie, aktualizowanie, przetwarzanie, zestawianie, publikowanie [...]. Efekty tego w jaki sposób przebiega w bibliotece przygotowywanie wymienionych zadań informacyjnych zależą właśnie od ZI.

\section{W kierunku strategii i polityki zarządzania informacją}

Zidentyfikowanie kluczowych obszarów ZI w bibliotece uświadamia nam, że nie możemy pozostawić ich przypadkowym, chaotycznym, niezaplanowanym i niekontrolowanym oddziaływaniom. W zakresie wspomnianych obszarów mieszczą się wszelkie działania usprawniające przepływ i wykorzystanie informacji $\mathrm{w}$ bibliotece $-\mathrm{z}$ wykorzystaniem technologii informacyjno-komunikacyjnych ${ }^{2}$, a więc przykładowo:

2 Więcej na temat istoty zarządzania informacją w: K. Materska: Przyczynek do jakości zarządzania informacja $i$ wiedza $w$ bibliotece akademickiej drugiej dekady XXI $w$. W: Zarządzanie jakościa w bibliotece. Praca zbiorowa pod red. M. Wojciechowskiej. Warszawa 2017, s. 11-22; K. Materska: Zarzadzanie informacja i wiedza. W: Nauka 
- zapewnienie dostępności (także kontrolę dostępu) - poprzez różne systemy w środowiskach rozproszonych, mobilnych, zdalnych; lokalizowanie informacji i odpowiednie organizowanie ich - co jest szczególnie ważne w przypadku różnych źródeł nieustrukturyzowanych; wyszukiwanie informacji znajdującej się $\mathrm{w}$ różnych lokalizacjach, $\mathrm{z}$ możliwością realizowania złożonych zapytań; porządkowanie wyników i tworzenie rankingów według różnych kryteriów (kategorii), odkrywanie danych (data discovery) - szybkie znajdowanie zależności pomiędzy danymi. Dostępność informacji związana jest ściśle $\mathrm{z}$ dzieleniem się informacją i wiedzą - umożliwia współpracę, skuteczne i efektywne dzielenie się informacją pomiędzy systemami, organizacjami i ludźmi; wymaganiem jest tworzenie strategii komunikacyjnych, a dla systemów ważna jest interoperacyjność;

- nieustanne dbanie o jakość informacji, procesów i usług informacyjnych - wyraża się w takich cechach jak np.: dokładność, spójność i integralność danych, istotność, ustrukturalizowanie informacji, celowość gromadzenia i wykorzystywania. W tym celu potrzebne są także szkolenia, treningi oraz aplikacje minimalizujące tworzenie błędów i pomyłek, kontrola danych; stosowanie certyfikacji systemów, stosowanie regulacji i standardów;

- zapewnienie bezpieczeństwa zasobów, procesów i systemów informacyjnych; nieodzowne jest wprowadzenie polityki bezpieczeństwa, prowadzenie audytu, podnoszenie świadomości bezpieczeństwa informacji i danych wśród pracowników;

- znaczące zwiększenie wykorzystywania (eksploatacji) zgromadzonych danych i informacji - stosowanie narzędzi analitycznych (rozwiązań do zastosowań ilościowych, statystycznych; modelowania danych); wizualizacja danych; prowadzenie analiz gdzie i kiedy informacja jest potrzebna; mobilny i zdalny dostęp do danych;

- kreowanie właściwej kultury informacyjnej, w tym rozpoznawanie wartości informacji, rozwijanie myślenia informacyjnego, kształtowanie wiedzy, nawyków i umiejętności w odniesieniu do danych, informacji i wiedzy, wyznaczanie ról i odpowiedzialności³

o informacji. Pod red. W. Babika. Kraków 2016, s. 359-385.

3 Więcej na temat kultury informacyjnej zob. np.: H. Batorowska: Kultura informacyjna $w$ perspektywie zmian $w$ edukacji. Warszawa 2009; B. Stefanowicz: Imperatyw kultury 
Wymienione obszary powinny znaleźć swoje odzwierciedlenie w ważnych dla wielu organizacji dokumentach, jakimi są strategia i polityka informacyjna. Ustalenia autorki artykułu wskazują, że niewiele polskich bibliotek posiada tego typu dokumenty. Ich istocie, proponowanej zawartości i formie poświęcony zostanie odrębny tekst; poniżej sygnalizowane są jedynie zadania obydwu dokumentów, które ułatwić mają kadrze menedżerskiej bibliotek myślenie nakierowane na sprawy związane $\mathrm{z}$ informacją.

Strategia [co? - cele] ogólnie definiuje charakter, misję i kierunki biblioteki. Nakierowana jest na długoterminowe relacje ze środowiskiem, wyszczególnia, co biblioteka zamierza robić $\mathrm{w}$ przyszłości. Strategie są formułowane i implementowane z intencją osiągnięcia określonych celów.

Polityka [jak? - zasady, procedury] mówi nam, co powinniśmy lub czego nie powinniśmy robić, aby przyczynić się do osiągnięcia organizacyjnych celów. Polityka jest zwięzłym dokumentem, który wyznacza odpowiedzialności i zasady. Wyjaśnia, jak cel może być osiągnięty i sprawia, że strategia staje się bardziej klarowna. Konkretne procedury są więc wywiedzione z polityk. (Procedura określa krok po kroku szczegóły tego, jak wykonać coś zgodnie z zasadami).

Za politykę informacyjną każdej instytucji, w tym także bibliotek, oraz diagnozę osiąganych $\mathrm{w}$ tym zakresie rezultatów odpowiedzialna jest kadra zarządzająca. Do jej zadań ZI na szczeblu strategicznym można zaliczyć:

- stworzenie i implementację polityki informacyjnej, standardów;

- szukanie wskazówek, narzędzi i najlepszych praktyk;

- rozwijanie inicjatyw wspierających ZI;

- rozpoznanie kompetencji informacyjnych kadry;

- szkolenia w zakresie ZI w bibliotece;

- integrację wymagań ZI ze strategią i planami rozwoju technologii informacyjnej;

- diagnozowanie stanu ZI.

Nie zwalnia to pracowników szczebla operacyjnego ze stosowania zasad, standardów i praktyk ZI, stosowania polityk, wskazówek i wytycznych wykonania swoich obowiązków, dokumentowania swoich aktywności i decyzji. Pracownicy są odpowiedzialni za ZI, z którą mają do czynienia podczas wykonywania swojej pracy. Jest oczywiste, że bez odpowiedniego

informacyjnej. „Zeszyty Naukowe Uniwersytetu Szczecińskiego” Nr 863, „Studia Informatica" Nr 36 (2015), s. 91-101. 
ukierunkowania (kierowania) ze strony władz biblioteki, zespół biblioteczny może przygotowywać i wykorzystywać informację w różnoraki sposób, czasami inaczej niż powinien - należy więc komunikować intencje, dostarczać wymaganej informacji, kontrolować.

\section{Brak zarządzania informacją - możliwe koszty}

Często zastanawiamy się, ile kosztuje nas w różnych sytuacjach brak natychmiastowej, relewantnej informacji. Choć mówiąc o kosztach najczęściej mamy na myśli kategorię ekonomiczną (finansową), to trzeba mieć na uwadze także koszty społeczne braku potrzebnej informacji (bardzo trudne do wyliczenia). W tym przypadku będą to negatywne efekty postrzegania biblioteki będące skutkiem zaniechania bądź niewystarczającego uświadomienia konieczności działań na polu ZI. Przykładowo wymienić można:

- przechowywanie (archiwizację) niepotrzebnej informacji - rodzi wzrost kosztów finansowych (zalecane postępowanie: od nadmiaru do umiaru);

- brak potrzebnej/aktualnej informacji na czas - prowadzi np.: do utraty grantu, projektu, braku rozwoju w określonym obszarze; są to tzw. koszty utraconych możliwości/korzyści;

- posługiwanie się informacją niesprawdzoną/niewiarygodną powodować może utratę zaufania użytkowników i innych interesariuszy;

- brak organizacji/dobrego dostępu do informacji - skutkuje stratą czasu pracowników i użytkowników.

\section{Efektywność zarządzania informacją w minimalizowaniu kosztów biblioteki}

ZI obejmuje procesy, funkcje, standardy i technologie, które umożliwiają, by wysokiej jakości informacja była tworzona, przechowywana, komunikowana, doceniana oraz wykorzystywana w efektywny i bezpieczny sposób - wspierając rozmaite cele biblioteki. W przeszłości organizacje stosowały „silosowe/magazynowe” oraz bieżące (często na zasadzie ad-hoc) podejście do ZI. Takie fragmentaryczne i reaktywne podejście do ZI znacząco podnosiło koszty ZI i redukowało jego efektywność i elastyczność. Funkcjonowanie organizacji informacyjnych liczących się z kosztami wymaga dziś strategicznego, planowego i szerokiego podejścia do ZI, zespo- 
łowego działania, skonsolidowanej architektury ZI integrującej rozproszone informacje, zapewniającej bezpieczeństwo, kontrolę dostępu i możliwość zarządzania treścią. W związku z przyjętym w artykule kontekstem finansów bibliotecznych, u podstaw działań z zakresu ZI tkwić powinna efektywność ekonomiczna. Jednym z jej przejawów jest wypracowanie w organizacji, jaką jest biblioteka, zasad i reguł uniwersalnych w tym sensie, że odnoszą się do zarządzania danymi, informacjami i treściami analogowymi i cyfrowymi zarazem; dotyczy to także stosowania krajowych i międzynarodowych standardów w działaniach informacyjnych, dążeń do organizowania i przetwarzania danych i informacji $\mathrm{w}$ ustrukturyzowanym środowisku ${ }^{4}$. Pomocne byłoby wykorzystywanie pomiędzy bibliotekami i innymi współpracującymi instytucjami kompatybilnych systemów spełniających kryteria interoperacyjności. Efektywne ZI umożliwia redukcję kosztów poprzez eliminację niepożądanej utraty informacji, a także powielania tych samych informacji; usuwanie (na czas) niepotrzebnych rekordów. Wymierne korzyści przynosi ZI także poprzez wspieranie współpracy i dzielenia się informacjami pomiędzy różnymi działami i bibliotekami, poprzez zdalny i na czas dostęp do informacji przez upoważnione osoby, dzielenie się usługami i systemami (pomiędzy bibliotekami). Poprawna implementacja odpowiednich systemów informacyjnych, zapewnienie poprawnych metadanych, agregacja danych i strukturyzacja informacji znajdujących się w różnych formatach, przekłada się na spore ułatwienia w zakresie analityki danych zarządczych wspierającej decyzje dotyczące kosztów funkcjonowania biblioteki, wspiera identyfikację powiązań pomiędzy ludźmi, obiektami, miejscami i zdarzeniami.

Można powiedzieć, że efektywne ZI umożliwia uwolnienie wartości tkwiącej w informacji i jej skuteczności, a taki zasób to niewątpliwy kapitał każdej biblioteki.

4 R. Vuorikari, Y. Punie, S. Carretero Gomez, G. Van den Brande: DigComp 2.0: The Digital Competence Framework for Citizens. Update Phase 1, The Conceptual Reference Model. Luxembourg Publication Office of the European Union 2016. 


\section{Bibliografia}

1. Batorowska H.: Kultura informacyjna $w$ perspektywie zmian w edukacji. Warszawa 2009.

2. Materska K.: Przyczynek do jakości zarzadzania informacją $i$ wiedzq $w$ bibliotece akademickiej drugiej dekady XXI w. W: Zarządzanie jakością w bibliotece. Praca zbiorowa pod red. M. Wojciechowskiej. Warszawa 2017, s. 11-22.

3. Materska K.: Zarządzanie informacja i wiedzą. W: Nauka o informacji. Pod red. W. Babika. Kraków 2016, s. 359-385.

4. Stefanowicz B.: Imperatyw kultury informacyjnej. „Zeszyty Naukowe Uniwersytetu Szczecińskiego” Nr 863, „Studia Informatica” Nr 36 (2015), s. 91-101.

5. Vuorikari R., Punie Y., Carretero Gomez S., Van den Brande G.: DigComp 2.0: The Digital Competence Framework for Citizens. Update Phase 1: The Conceptual Reference Model. Luxembourg Publication Office of the European Union 2016.

6. Zygała R.: Podstawy zarządzania informacja $w$ przedsiębiorstwie. Wroclaw 2007. 